\title{
Effect of Dietary Supplementation with L-Arginine and Vitamin C on Egg Production Performance for Matrouh Strain Hens
}

\author{
Elham S. Mohamed ${ }^{1 *}$, Abdella ${ }^{2}$ M. M., El-Sayaad ${ }^{2}$ G. A. $\operatorname{and~Hassan}^{1}$ I. I. \\ 1- Animal Production Res. Inst., Agric. Res. Center, Dokki, Giza, Egypt \\ 2-Poultry Production Dept., Fac. of Agric. Benha Univ., Egypt \\ *Corresponding author: elhamsalah985@gmail.com
}

\begin{abstract}
The present work was aimed to study the effect of dietary L-arginine level, vitamin C, and their interaction between them on some productive performance of Matrouh laying hens during the summer season. A $4 \mathrm{X} 3$ factorial treatment arrangement was carried out including four levels of dietary L-Arg (0.0, 0.4, 0.8, and 1.2 $\mathrm{g} / \mathrm{kg}$ diet) and three $\mathrm{VC}$ concentrations (0, 150, and $300 \mathrm{mg} / \mathrm{kg}$ diet). A total number of 108 Matrouh hens (Egyptian local strain) aged 64 weeks were randomly distributed into twelve treatment groups (three replicate each). The results obtained showed a significant $(\mathrm{p}<0.05)$ effect in live body weight due to dietary L-Arg and VC supplementation at 72 weeks of age only. Significant $(\mathrm{p}<0.05)$ differences were observed in feed intake and feed conversion ratio due to dietary L-Arg levels during all periods of estimation. Dietary L-Arg levels had significant $(\mathrm{P}<0.05)$ effects on the rate of egg prodction during the periods from 68-71 and 64-75 weeks of birds age. Significant $(\mathrm{p}<0.05)$ differences were observed in egg weight due to dietary L-Arg and VC levels during all periods of estimation except at 72-75 weeks of age. Dietary L-Arg levels had significant $(\mathrm{P}<0.05)$ effect on egg mass during the periods from 68-71,72-75 and 64-75 weeks of bird's age. The VC supplementation didn't have any significant effects on feed conversion ratio, egg production rate, egg weight, and egg mass. The interaction effects between dietary L-Arg and VC levels had a major influence $(\mathrm{p}<0.05)$ on body weight, feed consumption, feed conversion ratio, egg production rate, egg weight and egg mass. In conclusion, it could be concluded that Matrouh laying hens supplemented diet with L-Arg at a level of $1.2 \mathrm{~g}$ or VC at a level of $300 \mathrm{mg} / \mathrm{kg} \mathrm{diet}$, seemed to be adequate to achieve the favorite results and is recommended.
\end{abstract}

Keywords: L-arginine, vitamin C, laying hens, egg production, feed conversion

\section{Introduction}

Several studies showed a close correlation between the level of some amino acids in the blood and reproductive performance of poultry at various stages of the production cycle in poultry (Gabr, 2009). The L-arginine (L-Arg) is one of the 20 most common natural amino acids and classified as an essential amino acid for birds due to their inability to synthesize it. L-Arg is a biosynthesis substrate for several molecules, including protein, nitric oxide, creatine, ornithine, glutamate, polyamine, proline, glutamine, agmatine and dimethylarginine, thus serving a range of essential biological and physiological roles in poultry development (Khajali and Wideman, 2010). Arginine is also known to induce ovulation by enhancing luteinizing hormone (LH) release (Basiouni et al., 2006). Besides the requirement for L-Arg ranged from less than $0.70 \%$ of the diet for realistic diets to almost $1.8 \%$ for distilled diets, in which casein was the source of protein (Khajali and Wideman, 2010). Dietary supplementation of L-Arg above NRC (NRC, 1994) improved egg production, reproduction performance, enhanced cellular immunity and most semen parameters (Silva et al., 2012 and Youssef et al., 2015). Also increased body weight in Fayoumi and Golden Montazah laying hens (Youssef et al., 2016) also body weight was significantly increased in the commercial broiler (Zampiga et al., 2018). As well feed conversion significantly improved, as the dietary L-Arg level increased in laying hens (Youssef et al., 2015). Fouad et al (2012) and Yuan et al., (2015) said that L-Arg supplementation in poultry diets increases the production and the weight of eggs. Also, egg production traits were markedly improved by L-Arg supplemented in Silver Montazah chickens (Sabry et al 2016).

Hens reared under thermal conditions and hens reared under chronic heat stress and fed a diet supplemented with ascorbic acid had the greatest body weight and feed conversion rate compared with hens reared under chronic heat stress without supplementation (Attia et al., 2016). Also, laying Japanese quail the diet had $300 \mathrm{mg}$ ascorbic acid recorded the best $(\mathrm{P}<0.05)$ feed conversion (AbouKassem et al., 2020) while, Kadhim et al., (2019) reported no significant differences in average between control and experimental groups in feed conversion efficiency. Chung et al., (2005) found that supplemented birds of the vitamins $\mathrm{C}$ tended to maintain a better egg production rate. Also, dietary supplementation by $125 \mathrm{mg}$ vitamin E plus $200 \mathrm{mg}$ vitamin $\mathrm{C} / \mathrm{kg}$ of diet may increase egg production and improve egg quality in laying hens during heat stress (Çiftçi et al., 2005)

Therefore, the objective of the present study was to study the effect of dietary supplementation of 
L-arginine and ascorbic acid on some productive performances during the summer seasons for Matrouh chickens as local strain hens.

\section{Materials and Methods}

The latest research was conducted at the Inshas Poultry Breeding Research Station, Animal Production Research Institute, Agriculture Research Center, Ministry of Agriculture, Giza, Egypt, during the period from May 2018 to August 2018. The chemical analysis was carried out at the Laboratories of the Animal Production Research Institute, Ministry of Agriculture. A 4 x 3 factorial arrangement design was used in this experiment including four levels of L-Arg $(0,0.4,0.8$ and 1.2 $\mathrm{g} / \mathrm{kg} \mathrm{diet})$, three levels of $\mathrm{VC}(0,150$ and $300 \mathrm{mg} / \mathrm{kg}$ diet) and the interaction between them. A total number of 108 laying hens aged 64 weeks, were randomly selected from the farm flock and used in this experiment. All selected birds were randomly distributed into 12 treatments equal in number ( 9 hens / each treatment). Laying hens of each treatment were of nearly an equal average body weight and similar average daily egg production with no statistical differences. All birds of the experimental treatments were individually housed in wire-caged batteries $(45 \times 30 \times 35 \mathrm{~cm})$, and kept under the similar managerial, hygienic and environmental conditions. Birds were located in a temperature controlled room, and the photoperiod during the experimental period was fixed at $16 \mathrm{hrs}$ daily. Hens were fed ad-libitum, and during the experimental period, fresh water was available all the time (12 weeks). Birds were fed a basal laying diet formulated to cover the nutrient requirements of $\mathrm{M}$ laying hens recommendations according to Feed Composition Tables For Animal and Poultry Feedstuffs Used In Egypt (2001). Layers were fed either the basal diet with no supplementation (control) or supplemented with 0 , $0.4,0.8$ or $1.2 \mathrm{~g} \mathrm{~L}-\mathrm{Arg} / \mathrm{kg}$ diet and 0,150 or $300 \mathrm{mg}$ $\mathrm{VC} / \mathrm{kg}$ diet.

Feed components and chemical analysis of the experimental basal diet are presented in table (1). Birds of each experimental treatment were individually weighed to the nearest gram at the start of the experiment, and then every four weeks during the experimental period $(64,68,72$ and 76 weeks of age). Feed intake (FI) for birds within each treatment group was weekly recorded, and then it was averaged for each treatment and expressed as grams per bird per day during the periods from 64-68, 68-72 and 7276 weeks of bird's age. Feed conversion (FC) of birds was calculated as the number of grams of FI required to produce one gram of eggs during each experimental period as follows: -

$$
\mathrm{FC}=\frac{\text { Average } \mathrm{FI}(\mathrm{g})}{\text { Average egg } \operatorname{mass}(\mathrm{g})}
$$

During the whole experimental period, egg numbers and egg weight were individually recorded daily for hens within each experimental group. The weight of eggs was registered to the nearest gram. Egg production rate (\%) was calculated for each experimental group as follows: -

Egg production rate, $(\%) /$ hen $/$ day $=\frac{\text { Number of eggs produced }}{\text { Number of live hens }} \times 100$

By multiplying the total number of eggs by the mean egg weight for each group, egg mass was determined as follows: -

Egg mass, g/day =

Egg number/ hen /day X avergage egg weight (g)

For each experimental procedure, the egg number, average egg weight and egg mass were calculated every four weeks.

Data were statistically analyzed according to ANOVA procedures of SAS (SAS, 2012). Means differences were compared using Duncan's multiple range test (Duncan, 1955). 
Table 1. Feed ingredients and chemical analysis of the basal laying diet.

\begin{tabular}{|c|c|}
\hline Ingredients & $\%$ \\
\hline Yellow corn $\quad(8.5 \%)$ & 62.80 \\
\hline Wheat Bran $\quad(15.7 \%)$ & 10.00 \\
\hline Corn gluten meal (60\%) & 9.40 \\
\hline Soybean meal (44\%) & 8.00 \\
\hline Limestone $\quad\left(\mathrm{CaCo}_{3}\right)$ & 6.70 \\
\hline Di-calcium phosphate & 3.32 \\
\hline Salt $\quad(\mathrm{NaCl})$ & 0.34 \\
\hline Dl-Methionine $99 \%$ & 0.03 \\
\hline L-Lysine HCL & 0.11 \\
\hline Vit + Min. premix $*$ & 0.30 \\
\hline Total & 100 \\
\hline \multicolumn{2}{|l|}{ Chemical analysis: - } \\
\hline \multicolumn{2}{|l|}{$\overline{\text { a-Calculated analysis }} * *:-$} \\
\hline $\mathrm{ME}, \mathrm{Kcal} / \mathrm{kg}$. & 2728 \\
\hline Crude protein, $\%$ & 16.00 \\
\hline Crude fiber, $\%$ & 3.14 \\
\hline $\mathrm{EE}$ & 3.05 \\
\hline Calcium, $\%$ & 3.33 \\
\hline Ash \% & 3.14 \\
\hline Available phosphorus, $\%$. & 0.73 \\
\hline Lysine, \%. & 0.53 \\
\hline Methionine, \% & 0.72 \\
\hline Arginine & 0.75 \\
\hline \multicolumn{2}{|l|}{ b- Designed analysis $* * *:-$} \\
\hline 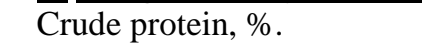 & 16.00 \\
\hline Crude fiber, $\%$. & 3.14 \\
\hline Ash \%. & 3.14 \\
\hline
\end{tabular}

*Vit. Min. premix: Each $2 \mathrm{~kg}$ of vitamin and mineral premix (Commercial source AGRIVET Co.) contains Vit. A. 12000000 IU, Vit. D 2000000 IU, Vit. E. 10000 mg, Vit. K3 2000 mg, Vit. B 100 mg, Vit. B 5000 mg, Vit. B6 1500 mg, Vit. B12 10 mg, Biotin 50 mg, Choline chloride 250000 mg, Pantothenic acid $10000 \mathrm{mg}$, Nicotinic acid $3000 \mathrm{mg}$, Folic acid $1000 \mathrm{mg}$, Manganese $60000 \mathrm{mg}$, Zinc $50000 \mathrm{mg}$, Iron $30000 \mathrm{mg}$, Copper $10000 \mathrm{mg}$, Iodine $1000 \mathrm{mg}$, Selenium $100 \mathrm{mg}$, Cobalt $100 \mathrm{mg}$, Carrier $\left(\mathrm{Ca} \mathrm{CO}_{3}\right)$ add to $2 \mathrm{~kg}$.

** Calculated in accordance with NRC (1994).

*** Designed according to the styles of AOAC (2005).

\section{Results and Discussion}

\subsection{Live body weight ( $\mathrm{LBW})$}

Results in Table (2) revealed that dietary LArg or VC levels had non-significant effects on LBW during all the experimental periods except at 72 weeks of age only which showed significant $(\mathrm{P}<0.05)$ variations. Birds fed of control group recorded the highest average of LBW (1611.5 g). While, dietary $300 \mathrm{mg} / \mathrm{kg}$ diet $\mathrm{VC}$ recorded the highest average of LBW (1583.7 g) during the period from $(64-75 \mathrm{wks})$. Whereas, the interaction between dietary L-Arg and VC levels had a significant $(\mathrm{P}<0.05)$ effect on LBW of layer hens at all periods of estimation. The best average of LBW (1721.3 g) was recorded in the interaction between dietary L$\operatorname{Arg}(1.2 \mathrm{~g} / \mathrm{kg}$ diet $)$ and VC levels $(0 \mathrm{mg} / \mathrm{kg}$ diet $)$. The previous results disagree with the findings of AbouKassem et al., (2020) who showed that the final body weight of laying Japanese quail fed diet supplemented with ascorbic acid or clay was significantly $(\mathrm{P}<0.05$ or 0.01$)$ increased compared to the control diet. Improving weight performance particularly during the starter period may be due to L-Arg, especially during the starting process, is considered an important amino acid for poultry since chicks do not have a functional biochemical urea cycle, are unable to synthesize L-Arg and thus need this amino acid to be supplied in the diet (Murakami et al., 2014).

\subsection{Feed intake (FI)}

Dietary L-Arg and the interactions between dietary L-Arg and VC levels had a significant $(\mathrm{P}<0.05)$ effects on average daily feed intake $(\mathrm{FI})$ of layers (Table, 2). The lowest average of feed intake was recorded in birds fed a diet supplemented with $0.8 \mathrm{~L}-\mathrm{Arg}, 150 \mathrm{mg}$ V.C $/ \mathrm{kg}$ diet and the interaction between $0.8 \mathrm{~L}$-Arg and $150 \mathrm{mg} / \mathrm{kg} \mathrm{VC}$ diet during the period from (64-75 wks) of age when compared with different treatments applied. Dietary VC supplementation showed a significant $(\mathrm{P}<0.05)$ effect on average FI during the period from $64-67$ wks of age only. The results obtained disagree with the findings of Youssef et al., (2015) who confirmed 
that feed intake did not generally differ significantly due to L-Arg supplementation.

Table 2. Least square means and standard error $(\bar{X} \pm S E)$ for live body weight and feed intake of Matrouh strain hens as affected by studied factors.

\begin{tabular}{|c|c|c|c|c|c|c|c|c|}
\hline \multirow[b]{2}{*}{ Items } & \multicolumn{5}{|c|}{ Live body weight (g) at weeks } & \multicolumn{3}{|c|}{ Feed intake (g/hen/day) at weeks } \\
\hline & 64 & 68 & 72 & 75 & $\begin{array}{l}\text { Average } \\
(64-75)\end{array}$ & 68-71 & $72-75$ & $\begin{array}{c}\text { Average } \\
(64-75)\end{array}$ \\
\hline LA & NS & NS & $*$ & NS & NS & $*$ & $*$ & $*$ \\
\hline 0.0 & $1524.7 \pm 18.2$ & $1627.6 \pm 39.7$ & $1675.8 \pm 46.8^{\mathrm{a}}$ & $1617.5 \pm 69.7$ & $1611.5 \pm 39.6$ & $87.18 \pm 2.77^{\mathrm{b}} 107.68 \pm 6.14^{\mathrm{a}}$ & ${ }^{\mathrm{a}} 110.75 \pm 2.10^{\mathrm{a}}$ & $101.87 \pm 2.97^{\mathrm{a}}$ \\
\hline 0.4 & $1462.2 \pm 30.1$ & $1561.2 \pm 50.3$ & $1511.7 \pm 63.6^{\mathrm{bc}}$ & $1562.8 \pm 53.2$ & $1524.5 \pm 44.3$ & $88.66 \pm 2.13^{\mathrm{a}} 102.88 \pm 4.99^{\mathrm{at}}$ & ab96.73 $\pm 2.07^{\mathrm{b}}$ & $96.09 \pm 2.43 \mathrm{~b}^{\mathrm{a}}$ \\
\hline 0.8 & $1420.7 \pm 36.9$ & $1537.1 \pm 45.6$ & $1473.1 \pm 44.5^{\mathrm{c}}$ & $1566.5 \pm 48.5$ & $1499.4 \pm 37.5$ & $80.75 \pm 1.29^{\mathrm{d}} 91.93 \pm 3.12^{\mathrm{b}}$ & $93.65 \pm 3.06^{\mathrm{b}}$ & $88.78 \pm 1.46^{\mathrm{c}}$ \\
\hline 1.2 & $1512.0 \pm 44.5$ & $1609.6 \pm 52.3$ & $1631.3 \pm 55.1^{\mathrm{ab}}$ & $1679.6 \pm 74.1$ & $1608.1 \pm 54.8$ & $83.56 \pm 2.49^{\mathrm{c}} 94.02 \pm 2.87 \mathrm{~b}^{\mathrm{a}}$ & $94.91 \pm 2.46^{\mathrm{b}}$ & $90.83 \pm 1.85^{\text {bc }}$ \\
\hline VC & NS & NS & $*$ & NS & NS & NS & NS & NS \\
\hline 0 & $1511.0 \pm 25.5$ & $1592.9 \pm 37.3$ & $1579.5 \pm 33.4^{\mathrm{ab}}$ & $1627.8 \pm 63.1$ & $1577.8 \pm 35.1$ & $83.81 \pm 2.39^{\mathrm{b}} 99.33 \pm 3.50$ & $98.46 \pm 2.68$ & $93.86 \pm 1.85$ \\
\hline 150 & $1452.1 \pm 30.4$ & $1557.8 \pm 37.6$ & $1512.5 \pm 52.5^{b}$ & $1562.4 \pm 41.7$ & $1521.1 \pm 36.6$ & $86.18 \pm 1.48^{\text {a }} 95.32 \pm 3.66$ & $96.87 \pm 2.66$ & $92.79 \pm 2.66$ \\
\hline 300 & $1476.5 \pm 35.1$ & $1601.0 \pm 48.2$ & $1626.9 \pm 59.3^{\mathrm{a}}$ & $1629.7 \pm 55.6$ & $1583.7 \pm 47.1$ & $85.13 \pm 2.32^{\mathrm{a}} 102.73 \pm 5.21$ & $101.69 \pm 3.26$ & $96.51 \pm 3.04$ \\
\hline
\end{tabular}

Interaction effects:

$\begin{array}{lllllllll}\text { LA } & \text { VC } & * & * & * & * & * & * & \text { NS }\end{array}$

$0 \quad 1512.6 \pm 15.5^{\mathrm{ab}} 1541.6 \pm 50.2^{\mathrm{ab}} 1561.0 \pm 36.3^{\mathrm{bc}} \quad 1466.6 \pm 155.0^{\mathrm{b}} 1520.6 \pm 50.8^{\mathrm{ab}} 76.15 \pm 0.69^{\mathrm{f}} 102.42 \pm 3.32 \quad 107.94 \pm 0.53^{\mathrm{ab}} 95.50 \pm 0.78^{\mathrm{bcd}}$

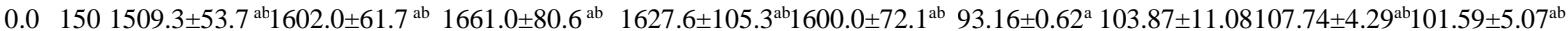

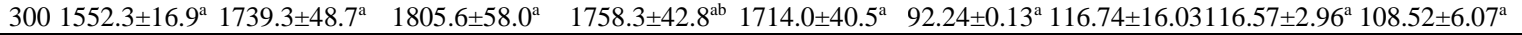

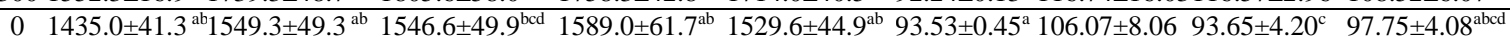

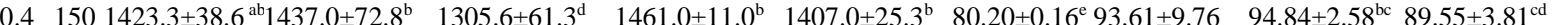
$\begin{array}{llllll}300 & 1528.3 \pm 66.0^{\mathrm{ab}} 1697.3 \pm 75.0^{\mathrm{a}} & 1683.0 \pm 76.3^{\mathrm{ab}} & 1638.6 \pm 147.0^{\mathrm{ab}} 1637.0 \pm 87.6^{\mathrm{ab}} & 92.24 \pm 0.53^{\mathrm{a}} 108.95 \pm 8.49 & 101.69 \pm 2.89^{\mathrm{bc}} 100.96 \pm 2.24^{\mathrm{abc}}\end{array}$

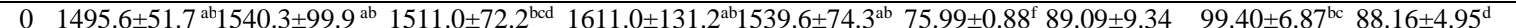

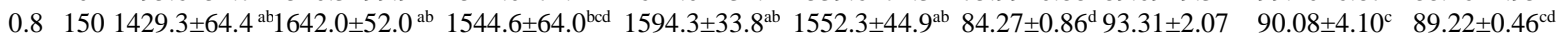

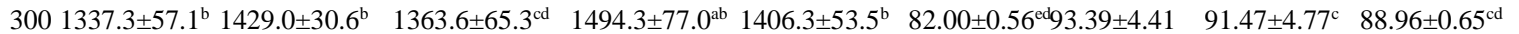

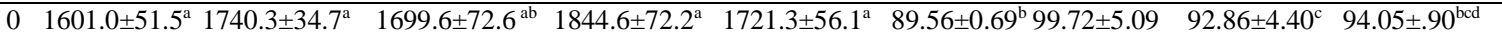
$1.21501446 .6 \pm 97.6^{\text {ab }} 1550.3 \pm 86.4^{\text {ab }} 1539.0 \pm 114.0^{\text {bcd }} 1566.6 \pm 134.5^{\text {ab }} 1525.3 \pm 107.3^{\text {ab } 87.08} \pm 1.67^{\mathrm{c}} 90.49 \pm 4.56 \quad 94.84 \pm 5.26^{\text {bc }} 90.80 \pm 3.35^{\text {bcd }}$ $3001488.3 \pm 72.2^{\mathrm{ab}} 1538.3 \pm 106.5^{\mathrm{ab}} 1655.3 \pm 106.5^{\mathrm{ab}} 1627.6 \pm 146.0^{\mathrm{ab}} 1577.6 \pm 105.2^{\mathrm{ab}} 74.02 \pm 1.09^{\mathrm{f}} 91.85 \pm 5.24 \quad 97.02 \pm 4.50^{\mathrm{bc}} 87.63 \pm 3.35^{\mathrm{d}}$

$(\bar{X} \pm S E)=$ Average \pm standard error, $\mathrm{LA}=\mathrm{L}$-arginine levels $(\mathrm{g} / \mathrm{kg}$ diet $), \mathrm{VC}=\mathrm{Vitamin} \mathrm{C}$ levels $(\mathrm{mg} / \mathrm{kg}$ diet $)$.

$a, b, c, d$ and e the meaning of having different letters in the same column is substantially different $(\mathrm{P} \leq 0.05)$.

$\mathrm{NS}=$ Not significant. $*=(\mathrm{P} \leq 0.05)$ and $* *=(\mathrm{P} \leq 0.01)$.

\subsection{Feed conversion (FC)}

The results of feed conversion (FC) and egg production rate (EPR \%) are presented in Tables (3). Significant $(\mathrm{P}<0.05)$ difference in FC and EPR \% were observed due to L-Arg level and the interaction between L-Arg and VC at all periods of estimation except the period from (64-67) and (72-75 wks) of age for FCR and EPR, respectively, While the insignificant difference due to the interaction was found during (64-71 wks) of age for EPR only. The results obtained agree with the findings of Youssef et al., (2015) who reported that the addition of L-Arg had a significant effect on FI and FC. The results show a numerical decrease in FI and improvement in FC by increasing L-Arg level especially after starter periods. Also, Youssef et al., (2016) reported that crested hens that treated with $4 \%$ Arg above NRC recorded the best feed conversion ratio.

3.4 Egg production (EP), egg weight (EW) and egg mass (EM)

In the experimental period, egg production rate and egg mass were significantly $(\mathrm{P} \leq 0.05)$ improved by feeding diets supplemented with L-Arg. Hens fed a $0.8 \mathrm{~g}$ L-Arg $\mathrm{kg}$ diet significantly increased egg production rate and egg weight, while these fed diet supplemented with $0.4 \mathrm{~g} \mathrm{~L}$-Arg/ $\mathrm{kg}$ diet significantly $(\mathrm{P} \leq 0.05)$ increased egg mass compared with the control group. Birds fed diets supplemented with different levels of VC insignificantly increased averages of egg production rate and egg mass. While, the interaction between $0.4 \mathrm{~g} \mathrm{~L}-\mathrm{Arg} \times 150 \mathrm{mg} \mathrm{VC}$ and between $1.2 \mathrm{~g} \mathrm{~L}-\mathrm{Arg}$ x $300 \mathrm{mg} \mathrm{VC} / \mathrm{kg}$ diet increased significantly averages of EW and EM, respectively, when compared with different interactions applied. Arginine is also known to be a potent secretagogue, increasing the bloodstream release of insulin, growth hormone, and IGF-A. It is part of the hormone vasotocin, which is involved in oviposition and uterine contraction (Rueda et al 2003). These results were in agreement with the findings of Youssef et al (2015) who noticed that adding Arg to the diet of two local strains Fayoumi and GM at levels 0.14 and 0.28 $\mathrm{g} / \mathrm{kg}$ of diet resulted in a significant increase $(\mathrm{P} \leq 0.05)$ in EP \% and egg mass at 75 wks of age, as well as, increasing Arg level to local Saudi laying hens to $9 \mathrm{~g} / \mathrm{kg}$ of diet over that required for the Leghorn breed requirements was found to improve hen day production percent (Silva et al 2012; Basiouni et al 2006 and Najib and Basiouni 2004). In this context, the stimulatory effect of Arg on luteinizing hormone (LH) secretion may be mediated through the stimulation of GnRH neurons in the hypothalamus and consequently, LH release. (Basiouni, 2009). On the other hand, Sharideh et al (2015) found that dietary supplementation of Arg (from 7.3 to $16.3 \mathrm{~g} / \mathrm{kg}$ diet) failed to change the rate of egg production. The present results show that the egg production traits were markedly improved in Arg supplemented group throughout the experimental period from 64 to 75 wks of age. Dietary L-Arg level 
had a significant $(\mathrm{P}<0.05)$ effect on EM values at 68$71,72-75$ and $64-75$ weeks of layers age. The best average of EM value $(25.16 \mathrm{~g} /$ hen/day) was observed in hens fed the diet supplemented with $0.4 \mathrm{~g} \mathrm{~L}$-Arg when compared with other treatments applied. The interactions between dietary L-Arg levels and VC had a significant effect $(\mathrm{P} \leq 0.05)$ on $\mathrm{EW}$ and $\mathrm{EM}$ at all periods of estimation except at $72-75 \mathrm{wks}$ for EW and 64-67 wks for EM, respectively.

Table 3. Least square means and standard error $(\bar{X} \pm S E)$ for feed conversion and egg production rate of Matrouh strain hens as affected by studied factors.

\begin{tabular}{|c|c|c|c|c|c|c|c|c|}
\hline \multirow[b]{2}{*}{ Items } & \multicolumn{4}{|c|}{ Feed conversion (g. feed/g. egg mass) at weeks } & \multicolumn{4}{|c|}{ Egg production $(\% /$ hen/day) at wks rate } \\
\hline & 64-67 & 68-71 & 72-75 & $\begin{array}{c}\text { Average } \\
(64-75)\end{array}$ & 64-67 & $68-71$ & 72-75 & $\begin{array}{c}\text { Average } \\
(64-75)\end{array}$ \\
\hline LA & NS & $*$ & $*$ & $*$ & NS & * & NS & $*$ \\
\hline 0.0 & $4.15 \pm 0.24$ & $5.12 \pm 0.34^{\mathrm{a}}$ & $5.23 \pm 0.33^{\mathrm{a}}$ & $4.76 \pm 0.16^{\mathrm{a}}$ & $43.39 \pm 1.98$ & $43.39 \pm 1.43^{\mathrm{b}}$ & $44.31 \pm 2.30$ & $43.69 \pm 1.02^{\mathrm{b}}$ \\
\hline 0.4 & $3.74 \pm 0.26$ & $3.91 \pm 0.16^{\mathrm{b}}$ & $4.01 \pm 0.20^{\mathrm{b}}$ & $3.87 \pm 0.16^{\mathrm{b}}$ & $48.41 \pm 2.88$ & $51.85 \pm 2.28^{\mathrm{a}}$ & $48.41 \pm 2.03$ & $49.56 \pm 2.13^{\mathrm{a}}$ \\
\hline 0.8 & $3.55 \pm 0.16$ & $3.74 \pm 0.17^{\mathrm{b}}$ & $4.10 \pm 0.17^{\mathrm{b}}$ & $3.78 \pm 0.11^{\mathrm{b}}$ & $45.50 \pm 2.23$ & $48.55 \pm 1.34^{\mathrm{a}}$ & $45.11 \pm 1.52$ & $46.38 \pm 1.35^{\mathrm{ab}}$ \\
\hline 1.2 & $3.63 \pm 0.16$ & $3.69 \pm 0.14^{\mathrm{b}}$ & $3.80 \pm 0.21^{\mathrm{b}}$ & $3.70 \pm 0.14^{b}$ & $46.16 \pm 1.84$ & $50.93 \pm 2.00^{\mathrm{a}}$ & $50.00 \pm 2.79$ & $49.03 \pm 1.82^{\mathrm{a}}$ \\
\hline VC & NS & NS & NS & NS & NS & NS & NS & NS \\
\hline 0 & $3.71 \pm 0.13$ & $4.29 \pm 0.23$ & $4.48 \pm 0.28$ & $4.13 \pm 0.16$ & $45.14 \pm 1.99$ & $46.43 \pm 1.75$ & $44.74 \pm 1.69$ & $45.44 \pm 1.49$ \\
\hline 150 & $3.86 \pm 0.21$ & $3.85 \pm 0.18$ & $4.15 \pm 0.18$ & $3.93 \pm 0.14$ & $45.73 \pm 2.02$ & $49.5 \pm 1.69$ & $46.83 \pm 1.48$ & $47.36 \pm 1.34$ \\
\hline 300 & $3.73 \pm 0.22$ & $4.21 \pm 0.32$ & $4.24 \pm 0.3$ & $4.03 \pm 0.22$ & $46.73 \pm 1.99$ & $50.1 \pm 1.86$ & $49.31 \pm 2.48$ & $48.71 \pm 1.68$ \\
\hline
\end{tabular}

Interaction effects:

\begin{tabular}{|c|c|c|c|c|c|c|c|c|c|}
\hline LA & $\mathrm{VC}$ & NS & $*$ & $*$ & $*$ & NS & * & * & $*$ \\
\hline \multirow{3}{*}{0.0} & 0 & $3.68 \pm 0.25$ & $5.15 \pm 0.53^{\mathrm{ab}}$ & $5.48 \pm 0.64^{\mathrm{a}}$ & $4.72 \pm 0.36^{\mathrm{ab}}$ & $41.67 \pm 2.38$ & $40.08 \pm 2.6^{\mathrm{b}}$ & $41.27 \pm 3.46^{\mathrm{b}}$ & $41.01 \pm 1.84^{\mathrm{c}}$ \\
\hline & 150 & $4.47 \pm 0.44$ & $4.69 \pm 0.39^{\mathrm{abc}}$ & $4.80 \pm 0.51^{\mathrm{ab}}$ & $4.60 \pm 0.16^{\mathrm{abc}}$ & $44.45 \pm 4.57$ & $46.03 \pm 1.73^{\mathrm{ab}}$ & $47.22 \pm 3.78^{\mathrm{ab}}$ & $45.9 \pm 1.34^{\mathrm{abc}}$ \\
\hline & 300 & $4.29 \pm 0.53$ & $5.51 \pm 0.91^{\mathrm{a}}$ & $5.41 \pm 0.69^{\mathrm{a}}$ & $4.97 \pm 0.32^{\mathrm{a}}$ & $44.05 \pm 4.29$ & $44.05 \pm 2.38^{\mathrm{ab}}$ & $44.44 \pm 5.34^{\mathrm{b}}$ & $44.18 \pm 1.08^{\mathrm{abc}}$ \\
\hline \multirow{3}{*}{0.4} & 0 & $3.58 \pm 0.21$ & $4.22 \pm 0.27^{\mathrm{bcd}}$ & $3.75 \pm 0.38^{\mathrm{bc}}$ & $3.84 \pm 0.22^{\text {cde }}$ & $51.98 \pm 2.86$ & $50.4 \pm 2.86^{\mathrm{ba}}$ & $50.79 \pm 3.46^{\mathrm{ab}}$ & $51.06 \pm 2.52^{\mathrm{ab}}$ \\
\hline & 150 & $3.54 \pm 0.58$ & $3.45 \pm 0.08 \mathrm{~cd}$ & $3.84 \pm 0.23^{\mathrm{bc}}$ & $3.59 \pm 0.26^{\mathrm{de}}$ & $45.63 \pm 5.93$ & $51.19 \pm 5.87^{\mathrm{a}}$ & $48.02 \pm 3.53^{\mathrm{ab}}$ & $48.28 \pm 4.71^{\mathrm{abc}}$ \\
\hline & 300 & $4.10 \pm 0.57$ & $4.06 \pm 0.22^{\mathrm{bcd}}$ & $4.44 \pm 0.36^{\mathrm{abc}}$ & $4.18 \pm 0.33^{\text {bdc }}$ & $47.62 \pm 6.77$ & $53.97 \pm 4.03^{\mathrm{a}}$ & $46.43 \pm 4.51^{\mathrm{b}}$ & $49.34 \pm 4.9^{\mathrm{abc}}$ \\
\hline \multirow{3}{*}{0.8} & 0 & $3.80 \pm 0.48$ & $3.81 \pm 0.47^{\mathrm{cd}}$ & $4.61 \pm 0.22^{\mathrm{ab}}$ & $4.04 \pm 0.29^{\text {bcde }}$ & $39.68 \pm 4.97$ & $45.64 \pm 2.21^{\mathrm{ab}}$ & $41.67 \pm 2.06^{\mathrm{b}}$ & $42.33 \pm 1.84^{\mathrm{bc}}$ \\
\hline & 150 & $3.51 \pm 0.09$ & $3.52 \pm 0.11^{\mathrm{cd}}$ & $3.84 \pm 0.27^{\mathrm{bc}}$ & $3.61 \pm 0.03^{\mathrm{de}}$ & $47.62 \pm 1.19$ & $51.59 \pm 1.73^{\mathrm{a}}$ & $46.03 \pm 2.21^{\mathrm{b}}$ & $48.41 \pm 0.4^{\mathrm{abc}}$ \\
\hline & 300 & $3.34 \pm 0.14$ & $3.90 \pm 0.28 b^{c d}$ & $3.86 \pm 0.19^{\mathrm{bc}}$ & $3.69 \pm 0.15^{\text {de }}$ & $49.21 \pm 2.78$ & $48.41 \pm 2.21^{\mathrm{ab}}$ & $47.62 \pm 2.99^{\mathrm{ab}}$ & $48.41 \pm 2.42^{\mathrm{abc}}$ \\
\hline \multirow{3}{*}{1.2} & 0 & $3.76 \pm 0.12$ & $3.98 \pm 0.26^{\mathrm{bcd}}$ & $4.07 \pm 0.50^{\mathrm{bc}}$ & $3.92 \pm 0.24^{\text {cde }}$ & $47.22 \pm 1.43$ & $49.6 \pm 3.78^{\mathrm{ab}}$ & $45.24 \pm 2.38^{b}$ & $47.35 \pm 1.92^{\mathrm{abc}}$ \\
\hline & 150 & $3.94 \pm 0.33$ & $3.72 \pm 0.10^{\mathrm{cd}}$ & $4.11 \pm 0.11^{\mathrm{bc}}$ & $3.90 \pm 0.10^{\text {cde }}$ & $45.24 \pm 5.46$ & $49.21 \pm 3.53^{\mathrm{ab}}$ & $46.03 \pm 3.91^{\mathrm{b}}$ & $46.82 \pm 3.64^{\mathrm{abc}}$ \\
\hline & 300 & $3.21 \pm 0.17$ & $3.36 \pm 0.22^{\mathrm{d}}$ & $3.23 \pm 0.08^{c}$ & $3.26 \pm 0.12^{\mathrm{e}}$ & $46.03 \pm 2.78$ & $53.97 \pm 3.78^{\mathrm{a}}$ & $58.73 \pm 3.91^{\mathrm{a}}$ & $52.91 \pm 3.4^{\mathrm{a}}$ \\
\hline
\end{tabular}

$(\bar{X} \pm S E)=$ Average \pm standard error, $\mathrm{LA}=\mathrm{L}$-arginine levels $(\mathrm{g} / \mathrm{kg}$ diet $), \mathrm{VC}=\mathrm{Vitamin} \mathrm{C}$ levels $(\mathrm{mg} / \mathrm{kg}$ diet $)$. a,b,c,d and e the meaning of having different letters in the same column is substantially different $(\mathrm{P} \leq 0.05)$. NS $=$ Not significant. $*=(\mathrm{P} \leq 0.05)$.

Table 4. Least square means and standard error $(\bar{X} \pm S E)$ for egg weight and egg mass of Matrouh strain hens as affected by studied factors.

\begin{tabular}{|c|c|c|c|c|c|c|c|c|c|}
\hline \multirow{2}{*}{\multicolumn{2}{|c|}{ Items }} & \multicolumn{4}{|c|}{ Egg weight (g) at weeks } & \multicolumn{4}{|c|}{ Egg mass (g/hen/day) at wks } \\
\hline & & 64-67 & 68-71 & 72-75 & $\begin{array}{c}\text { Average } \\
(64-75)\end{array}$ & 64-67 & 68-71 & 72-75 & $\begin{array}{c}\text { Average } \\
(64-75)\end{array}$ \\
\hline \multicolumn{2}{|c|}{$\mathbf{L A}$} & NS & NS & $\mathrm{NS}$ & NS & NS & * & $*$ & $*$ \\
\hline \multicolumn{2}{|c|}{0.0} & $49.33 \pm 0.60$ & $49.03 \pm 0.80$ & $49.02 \pm 0.80$ & $49.17 \pm 0.55$ & $21.44 \pm 1.11$ & $21.23 \pm 0.65^{\mathrm{b}}$ & $21.74 \pm 1.19^{\mathrm{b}}$ & $21.47 \pm 0.50^{\mathrm{b}}$ \\
\hline \multicolumn{2}{|c|}{0.4} & $50.57 \pm 0.71$ & $50.98 \pm 0.88$ & $50.62 \pm 0.84$ & $50.74 \pm 0.76$ & $24.53 \pm 1.57$ & $26.43 \pm 1.26^{\mathrm{a}}$ & $24.53 \pm 1.20^{\mathrm{ab}}$ & $25.16 \pm 1.20^{\mathrm{a}}$ \\
\hline \multicolumn{2}{|c|}{0.8} & $50.91 \pm 0.61$ & $50.96 \pm 0.54$ & $50.98 \pm 0.52$ & $50.94 \pm 0.51$ & $23.08 \pm 0.97$ & $24.71 \pm 0.62^{\mathrm{a}}$ & $22.99 \pm 0.78^{\mathrm{ab}}$ & $23.59 \pm 0.57^{\mathrm{ab}}$ \\
\hline \multicolumn{2}{|c|}{1.2} & $50.35 \pm 0.60$ & $50.48 \pm 0.56$ & $50.99 \pm 0.69$ & $50.59 \pm 0.54$ & $23.16 \pm 0.72$ & $25.65 \pm 0.85^{\mathrm{a}}$ & $25.45 \pm 1.34^{\mathrm{a}}$ & $24.75 \pm 0.77^{\mathrm{a}}$ \\
\hline \multicolumn{2}{|c|}{$\mathbf{V C}$} & NS & NS & NS & NS & NS & NS & $\mathrm{NS}$ & NS \\
\hline \multicolumn{2}{|c|}{0} & $50.80 \pm 0.57$ & $50.74 \pm 0.62$ & $50.43 \pm 0.87$ & $50.67 \pm 0.62$ & $22.90 \pm 1.00$ & $23.53 \pm 0.85$ & $22.61 \pm 1.04$ & $23.01 \pm 0.78$ \\
\hline \multicolumn{2}{|c|}{150} & $50.10 \pm 0.66$ & $50.50 \pm 0.63$ & $50.43 \pm 0.61$ & $50.34 \pm 0.57$ & $22.90 \pm 1.04$ & $25.02 \pm 0.99$ & $23.60 \pm 0.75$ & $23.84 \pm 0.76$ \\
\hline \multicolumn{2}{|c|}{300} & $49.98 \pm 0.39$ & $49.85 \pm 0.67$ & $50.34 \pm 0.44$ & $50.07 \pm 0.43$ & $23.36 \pm 1.01$ & $24.96 \pm 0.97$ & $24.81 \pm 1.25$ & $24.38 \pm 0.84$ \\
\hline \multicolumn{10}{|c|}{ Interaction effects: } \\
\hline \multirow[t]{2}{*}{ LA } & $\mathbf{V C}$ & $*$ & $*$ & NS & $*$ & NS & $*$ & $*$ & $*$ \\
\hline & 0 & $50.08 \pm 1.30^{\mathrm{ab}}$ & $50.41 \pm 1.36^{\mathrm{ab}}$ & $48.84 \pm 2.45$ & $49.82 \pm 1.38^{\mathrm{ab}}$ & $20.91 \pm 1.62$ & $20.27 \pm 1.88^{\mathrm{c}}$ & $20.23 \pm 2.24^{\mathrm{b}}$ & $20.47 \pm 1.43^{\mathrm{c}}$ \\
\hline \multirow[t]{2}{*}{0.0} & 150 & $47.91 \pm 0.32^{\mathrm{b}}$ & $47.95 \pm 0.49^{b}$ & $48.27 \pm 0.88$ & $48.10 \pm 0.37^{\mathrm{b}}$ & $21.32 \pm 2.35$ & $22.05 \pm 0.60^{\mathrm{abc}}$ & $22.82 \pm 2.01^{\mathrm{b}}$ & $22.07 \pm 0.47^{\mathrm{abc}}$ \\
\hline & 300 & $50.02 \pm 1.01^{\mathrm{ab}}$ & $48.73 \pm 2.01^{\mathrm{b}}$ & $49.94 \pm 0.54$ & $49.58 \pm 0.88^{\mathrm{ab}}$ & $22.11 \pm 2.53$ & $21.38 \pm 0.69^{\mathrm{bc}}$ & $22.16 \pm 2.51^{\mathrm{b}}$ & $21.88 \pm 0.22^{\mathrm{bc}}$ \\
\hline \multirow{3}{*}{0.4} & 0 & $50.58 \pm 1.68^{\mathrm{ab}}$ & $50.00 \pm 2.18^{\mathrm{ab}}$ & $49.90 \pm 2.46$ & $50.18 \pm 2.07^{\mathrm{ab}}$ & $26.29 \pm 1.69$ & $25.07 \pm 0.35^{\mathrm{abc}}$ & $25.43 \pm 2.67^{\mathrm{ab}}$ & $25.60 \pm 1.49^{\mathrm{ab}}$ \\
\hline & 150 & $51.87 \pm 1.16^{\mathrm{a}}$ & $53.08 \pm 0.39^{\mathrm{a}}$ & $51.86 \pm 1.04$ & $52.29 \pm 0.82^{\mathrm{a}}$ & $23.79 \pm 3.46$ & $27.22 \pm 3.31^{\mathrm{a}}$ & $24.94 \pm 2.18^{\mathrm{ab}}$ & $25.31 \pm 2.80^{a b c}$ \\
\hline & 300 & $49.26 \pm 0.40^{\mathrm{ab}}$ & $49.88 \pm 1.05^{\mathrm{ab}}$ & $50.09 \pm 0.44$ & $49.73 \pm 0.36^{\mathrm{ab}}$ & $23.50 \pm 3.53$ & $26.99 \pm 2.58^{\mathrm{a}}$ & $23.21 \pm 2.04^{\mathrm{b}}$ & $24.57 \pm 2.62^{\mathrm{abc}}$ \\
\hline \multirow{3}{*}{0.8} & 0 & $52.02 \pm 1.23^{\mathrm{a}}$ & $51.67 \pm 1.06^{\mathrm{ab}}$ & $51.77 \pm 0.98$ & $51.80 \pm 0.99 a$ & $20.54 \pm 2.26$ & $23.56 \pm 1.08^{\mathrm{abc}}$ & $21.59 \pm 1.36^{\mathrm{b}}$ & $21.90 \pm 0.74^{\mathrm{bc}}$ \\
\hline & 150 & $50.52 \pm 0.82^{\mathrm{ab}}$ & $51.43 \pm 0.37^{\mathrm{ab}}$ & $51.19 \pm 0.41$ & $51.03 \pm 0.33^{\mathrm{ab}}$ & $24.04 \pm 0.45$ & $26.52 \pm 0.69^{\mathrm{ab}}$ & $23.55 \pm 0.95^{\mathrm{b}}$ & $24.70 \pm 0.04^{\mathrm{abc}}$ \\
\hline & 300 & $50.19 \pm 1.17^{\mathrm{ab}}$ & $49.79 \pm 1.13^{\mathrm{ab}}$ & $49.99 \pm 1.13$ & $49.99 \pm 1.10^{\mathrm{ab}}$ & $24.64 \pm 1.02$ & $24.06 \pm 0.71^{\mathrm{abc}}$ & $23.83 \pm 1.79^{b}$ & $24.18 \pm 1.09^{\mathrm{abc}}$ \\
\hline \multirow{3}{*}{1.2} & 0 & $50.51 \pm 0.45^{\mathrm{ab}}$ & $50.88 \pm 0.24^{\mathrm{ab}}$ & $51.20 \pm 1.08$ & $50.88 \pm 0.44^{\mathrm{ab}}$ & $23.86 \pm 0.88$ & $25.22 \pm 1.81^{\mathrm{abc}}$ & $23.20 \pm 1.59^{\mathrm{b}}$ & $24.09 \pm 0.95^{\mathrm{abc}}$ \\
\hline & 150 & $50.09 \pm 1.89^{\mathrm{ab}}$ & $49.55 \pm 0.93^{\mathrm{ab}}$ & $50.41 \pm 1.58$ & $49.92 \pm 1.24^{\mathrm{ab}}$ & $22.45 \pm 1.96$ & $24.31 \pm 1.26^{\mathrm{abc}}$ & $23.08 \pm 1.20^{\mathrm{b}}$ & $23.28 \pm 1.19^{a b c}$ \\
\hline & 300 & $50.46 \pm 0.72^{\mathrm{ab}}$ & $51.00 \pm 1.49^{\mathrm{ab}}$ & $51.37 \pm 1.34$ & $50.97 \pm 1.21^{\mathrm{ab}}$ & $23.19 \pm 1.11$ & $27.41 \pm 1.12^{\mathrm{a}}$ & $30.06 \pm 1.26^{\mathrm{a}}$ & $26.89 \pm 1.12^{\mathrm{a}}$ \\
\hline
\end{tabular}

$(\bar{X} \pm S E)=$ Average \pm standard error, LA $=$ L-arginine levels $(\mathrm{g} / \mathrm{kg}$ diet $), \mathrm{VC}=\mathrm{Vitamin} \mathrm{C}$ levels $(\mathrm{mg} / \mathrm{kg}$ diet $)$. 
$\mathrm{a}, \mathrm{b}$ and $\mathrm{c}$ the meaning of having different letters in the same column is substantially different $(\mathrm{P} \leq 0.05)$. NS= Not significant. $*=(\mathrm{P} \leq 0.05)$.

Conclusion

In conclusion, dietary supplementation Arg from 64 to 75 wks of age might have the potential to improve feed intake, feed conversion, egg production, egg weight and egg mass. The results of this study indicate that diets containing $0.4 \mathrm{~g} \mathrm{~L}$-Arg or $150 \mathrm{mg} / \mathrm{kg} \mathrm{VC/kg} \mathrm{diet,} \mathrm{and} \mathrm{the} \mathrm{interaction}$ between dietary $1.2 \mathrm{~g} / \mathrm{kg} \mathrm{L}$-arginine with $300 \mathrm{mg} / \mathrm{kg}$ diet VC improved the productive performance of Matrouh laying hens.

\section{References}

Abou-Kassem DE; Abd El-Hack ME; Taha AE, Ajarem JS; Maodaa SN and Allam AA (2020) Detoxification impacts of ascorbic acid and clay on laying Japanese quail fed diets polluted by various levels of cadmium. Animals, 10, 372:118.

Attia YA; Abd El-Hamid E; Abedalla AA; Berika MA; Al-Harthi MA; Kucuk O; Sahin K and Abou-Shehema BM (2016) Laying performance, digestibility and plasma hormones in laying hens exposed to chronic heat stress as affected by betaine, vitamin $\mathrm{C}$, and/or vitamin $\mathrm{E}$ supplementation. Springer Plus 5:1619.

Basiouni G.; Najib H; Zaki MM and Al-Ankari AS (2006) Influence of extra supplementation with arginine and lysine on overall Performance, ovarian activities and humoral immune response in local Saudi hens. Int. J. Poult. Sci. 5:441-448.

Basiouni, GF (2009) The Effect of feeding an extra amount of arginine to local Saudi hens on luteinizing hormone secretion. J. Biolog. Sci., 9: 617-620.

Chung MK; Choi JH; Chung YK and Chee KM (2005) Effects of dietary vitamins $\mathrm{C}$ and $\mathrm{E}$ on egg shell quality of broiler breeder hens exposed to heat stress. Asian-Aust. J. Anim. Sci. Vol 18, No. 4: 545-551.

Çiftçi M., Nihat Ertas, $O$ and Güler T (2005) Effects of vitamin $\mathrm{E}$ and vitamin $\mathrm{C}$ dietary supplementation on egg production and egg quality of laying hens exposed to a chronic heat stress. Revue Méd. Vét., 156, (2):107-111.

Duncan, DB (1955) Multiple range and multiple F tests. Biometrics. 11, 1-42.

Feed Composition Tables for Animal and Poultry Feedstuffs Used in Egypt (2001) Technical bulletin No. 1, Central Lab for Feed and Food; Ministry of Agric., Egypt.

Fouad, AM; El-Senousey, HK; Yang XJ and Yao, JH (2012). Role of dietary L-arginine in poultry production. International Journal of Poultry Science 11 (11): 718-729.

Gabr, Sh.A (2009) The relay of sexual puberty in rabbit male by L-tyrosine or carnitine treatment. J. Agric. Res. Kafrelsheikh Univ., 35(1) 56-68.
Kadhim MJ; Al-Shammari KA; Ulsagheer, MK and Rmul, MR (2019) Effect of addition date molasses or/ and ascorbic acid with/without feeding method in some productive performance of broiler chickens Ross 308. Journal of Physics: Conf. Series: 1-10.

Khajali F. and Wideman RF (2010) Dietary arginine: Metabolic environmental, immunological and physiological interrelationships. World's Poult. Sci. J., 66: 751-766.

Murakami AE; Rodrigueiro, RJ; Santos, TC; Ospina-Rojas, IC and Rademacher, M (2014) Effects of dietary supplementation of meat-type quail breeders with guanidino acetic acid on their reproductive parameters and progeny performance. Poultry Science 93, 2237-2244.

Najib $H$ and Basiouni G (2004) Determination of the nutritional requirements of Baladi chickens: 1. Effect of Arginine inclusion, in excess of the leghorn requirement, on performance of the Saudi baladi chickens. Sci. J. King Faisal Univ. Basic Applied Sci. 5 131-144.

NRC (1994). National Research Council, Nutrient Requirements of Poultry. $9^{\text {th }}$ Ed, National Academic of Science. Washington, DC. USA.

Rueda E; Michelangeli, $C$ and Gonzalez-mujica $F$ (2003) L-Canavanine inhibits L-arginine uptake by broiler chicken intestinal brush border membrane vesicles. Arginine, Egg Production, Reproduction and Immune Response. British Poult. Sci.44: 620-625.

SAS (2012) Statistical Analysis System, SAS for Windows. Version 9.4. SAS Institute Inc. Cary, NC, USA.

Sharideh H; Esmaeile Neia L; Zaghari M; Zhandi, M; Akhlaghi, A and Lotfi L (2015). Effect of feeding guanidinoacetic acid and Larginine on the fertility rate and sperm penetration in the perivitelline layer of aged broiler breeder hens. J. of Anim. Physiol. and Anim. Nutr. 1-7.

Silva LM; Murakami AE; Fernandes, JI; Dalla Rosa D and Urgnani JF (2012) Effects of dietary arginine supplementation on broiler breeder egg production and hatchability. Brazilian J. of Poult. Sci.14: 267-273.

Youssef SF; Badawy MI and Abd El-Halim HAH (2016) Effect of L- arginine supplementation on productive, reproductive performance, immune response and gene expression in two local chicken strains. 2 -Responses of offspring. Egypt. Poult. Sci., 36: 825 -839.

Youssef SF; Shaban SAM and Inas I Ismail (2015) Effect of L-arginine supplementation on productive, reproductive performance, immune response and gene expression in tow local chicken strains. 1-Egg production, reproductive 
performance and immune response. Egypt.

Poult. Sci., 35 :573-590.

Yuan C; Li JM; Ding Y; He Q; Yan HX; Lu JJ and Zou XT (2015). Estimation of L-arginine requirement for Xinyang Black laying hens from 33 to 45 weeks of age. J. Appl. Poult. Res. 24:463-469.
Zampiga M; Laghi L; Petracci M; Zhu C; Meluzzi A; Dridi S and Sirri F (2018). Effect of dietary arginine to lysine ratios on productive performance, meat quality, plasma and muscle metabolomics profile in fast-growing broiler chickens. Journal of Animal Science and Biotechnology 9:79-93.

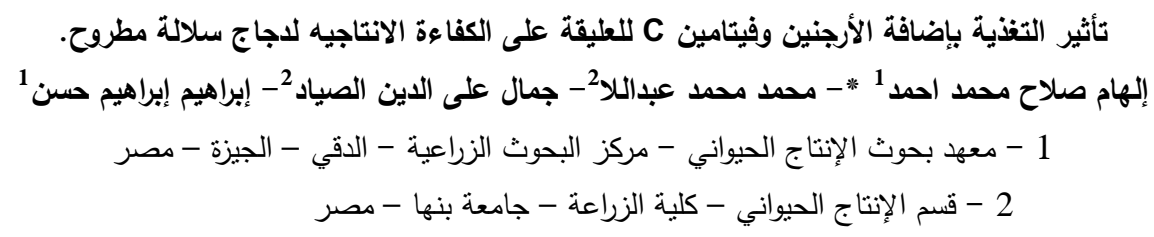

*Corresponding author: elhamsalah985@gmail.com

\begin{abstract}
أجري هذا البحث لدراسة ناثير اضافة مستوبات الحمض الأميني ال-أرجنين وفيتامين ج للعليقة والتذاخل بينهم على الكفاءة الإنتاجية لاجاج سلالة مطروح خلال فصل الصيف.

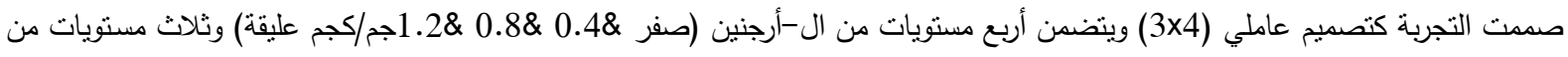

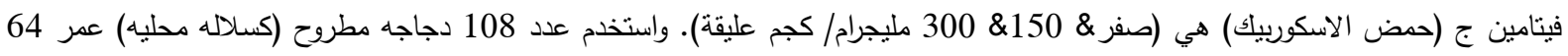
أسبوع اختيرت عشوائيا ووزعت الى 12 مجموعه (بكل مجموعة ثلاث مكررات). أوضحت النتائج وجود تأثثرات معنوية (P<0.05) في وزن الجسم الحي عند عمر 72 أسبوع من العمر فقط نتيجة إضافة ال-أرجنين وفيتامين ج للعليقة. أدت إضافة ال-أرجنين للعليقة الي ظهور تأثير معنوي (P>0.05) على معدل استهلاك العلف العان وكفاءة التحويل الغذائي طوال فترات

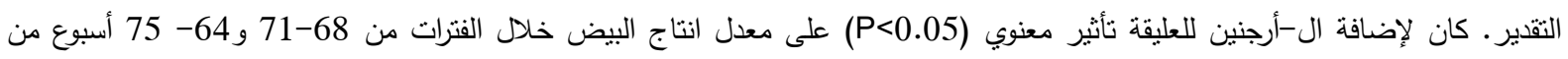

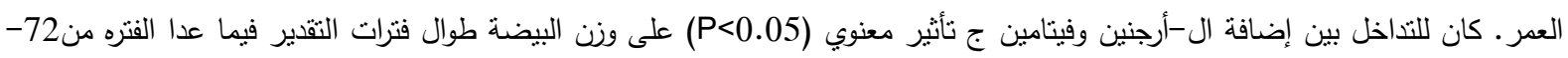

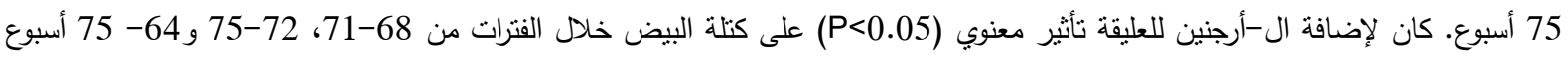

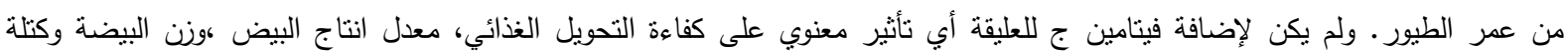

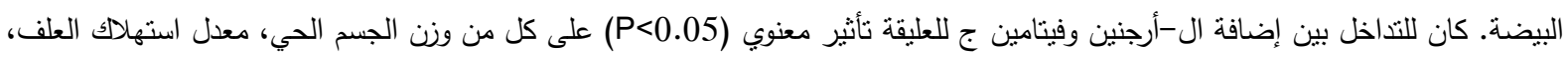
كفاءة التحويل الغذائي، معدل انتاج البيض، وزن البيضة وكتلة البيضة. خلصت هده الدراسة الي ان تغدية دجاج سلالة مطروح على عليقة مضاف اليها الحمض الاميني ال- أرجنين بمعدل 1.2 جم / كجم او فيتامين ج بمعدل 300 مليجرام / كجم عليقة قد سجلت أفضل النتائج ويمكن التوصية باستخدامها. الكلمات الدالة: ال -أرجنين، فيتامين C، الدجاج البياض، انتاج البيض، العلف المسنهلك.
\end{abstract}

